\title{
Foreword for Diaspora Language Contact: The Speech of Croatian Speakers Abroad
}

Books and articles about language contact have been pouring from the presses in great numbers for several decades now, which makes it hard for yet another book on the subject to stand out. This book, given its specialized focus, might seem at first glance to fall into the yet-another-book category. It does not. Its appeal to an audience of Slavic linguists is obvious, but it will also appeal to a much broader audience, because it addresses core issues in language contact research in novel and particularly effective ways. First, the editors provided the authors of the ten case studies - which focus on diasporic Croatian communities in nine countries with detailed guidelines for their chapters, thus ensuring parallel organization and therefore ease of comparability across all ten of those chapters. Second, following an introduction and three other stage-setting chapters, chapter 5, cowritten by authors of the case studies, provides an overview of the ten communities and their sociolinguistic settings. This chapter highlights the similarities and differences among the ten contact situations. Third, chapter 2, written by the first editor, discusses theoretical approaches to the study of language contact and situates the Croatian diaspora within the research area; the authors of the case studies have generally followed his lead, adopting his terminology and framing their analyses in ways that work well with his approach.

The result of these three editorial choices is a book which, while encompassing considerable diversity, forms a coherent whole. Readers will learn a great deal from any one chapter, and they will also be able to follow particular sociolinguistic and linguistic features through the ten case studies. The fact that the case studies fit together makes the book especially valuable. All of them contain detailed sociolinguistic information about the community as well as spoken data elicited by various means from community members. Several topics appear in most or all of the case studies. Among them are the analysis of socioeconomic dominance, language shift, and other sociolinguistic factors, code-switching, lexical transference (a term preferred by these authors to 'borrowing' and interference'), loan translations, word order features, syntactic calques, case morphology (a frequent partial casualty in these contact situations), gender, and discourse markers. Readers interested in attrition, or degree of nativization of loanwords, or the maintenance (or not) of immigrant languages, or any number of other topics that recur in the book will find rich material for study here.

Reading these chapters gave me a strong feeling of nostalgia, together with regret for a long-ago missed opportunity. In 1965-66 I spent a year in the old Yugoslavia doing library research and fieldwork for a dissertation project on word 
formation in dialects of the language then known as Serbo-Croatian (or CroatoSerbian), primarily Croatian, Serbian, and Montenegrin dialects. I had no particular interest in language contact back then, and it wasn't until I read this book that I fully realized how much I had overlooked. For instance, I knew nothing about code-switching at the time; and yet it arose as an issue in my research, because to collect dialect features in villages I had to try to avoid having consultants codeswitch to the standard dialect I spoke. And I remember being fascinated by Rešetar's 1911 monograph on Molise Croatian (Die serbokroatischen Kolonien Süditaliens), but though my dissertation notes the loss of the neuter gender in Molise Croatian noun declension, I don't think I even mentioned the probable influence of Italian on that development. Now that it's many decades too late, I wish I had been able to predict my future passion for contact phenomena; it would have improved the dissertation.

Thanks to publications like this book and other work on language contact, language contact is on so many linguists' agendas that young scholars are of course much less likely nowadays to overlook opportunities to study it. The book makes a major contribution to the field: I am confident that it will both educate readers and inspire further research in the areas it covers, especially (but not only) language contacts in diasporic communities. I recommend it wholeheartedly to everyone with an interest in language contact.

Sarah Thomason

University of Michigan, April 2020 